\title{
Evaluation of School Operational Assistance by using CIPP Model in Indonesia Private Islamic Elementary School
}

\author{
Allan Setyoko ${ }^{1}$, Billy Tunas ${ }^{2}$, Widodo Sunaryo ${ }^{3}$ \\ Post Graduate Program, Universitas Pakuan Bogor, Indonesia \\ lallan_setyoko@yahoo.com
}

\begin{abstract}
The purpose of this study was to determine the effectiveness of the implementation of the School Operational Assistance on private Islamic Elementary School in the city of Jambi, Indonesia. This study used a descriptive qualitative approach with a concept of a comprehensive evaluation program that includes context, input, process, and product (CIPP). Data were collected through observation, interviews, documentation, Focus Group Discussion and triangulation. The research was conducted in the respective schools in Jambi with data sources from Head of Administration Office of the Ministry of Religious Affairs Jambi Province, Head of Islamic Education Regional Office of the Ministry of Religious Jambi Province, Head of Sub-Division of Administration Office of Religious Affairs Jambi City, Head Islamic Education section of the Office of Religious Affairs Jambi City, Chief of the school, Teachers, Administration, and School Committee. Ratings for each aspect of the evaluation focus categorized into five levels, namely: very good, good, fairly good, poor and very poor. The results of this study show that the effectiveness of School Operational Assistance program was in the category of "Good". The results also showed it was still necessary to disseminate information on activities program routinely to all citizens of the school stakeholders.
\end{abstract}

Keywords: program evaluation, School Operational Assistance, implementation, context, input, process, and product (CIPP).

\section{INTRODUCTION}

To support the policy of nine years compulsory basic education, Indonesian government implemented the program of the School Operational Assistance or Bantuan Operasional Sekolah (BOS). Through the BOS program, learners at the level of basic education will be exempted from the obligation to pay school operational costs. School Operational Assistance (BOS), which is directly managed by the school include fees for enrollment, monthly school fees, examination fees, costs of materials and practices. The above fees are not included for the cost of investment and the provision of school infrastructure, teacher salaries and other education personnel, as well as the cost of increasing the quality of teachers. Use of the funds should be based on agreements and a joint decision between BOS School Management Team, Teachers Council and the School Committee. The results of the above agreement should be put in writing in the form of minutes of the meeting and signed by the meeting participants. Associated with the implementation of the BOS program in the city of Jambi, schools that received the BOS funds must follow the rules that have been set in terms of management, use, and accountability that must be effective and efficient.

However, the results of the monitoring and evaluation team in Jambi City revealed that 500 parents in 35 schools amounting to 92.40 percent of parents do not know the BOS reports and 100 percent do not see the notice board schools on the use of BOS. In addition, 94.60 percent of parents do not participate in planning BOS and provide input / advice to the school.

In order to maintain the quality of the effective and efficient BOS program implementation, it is necessary to process continuous control and regular evaluation by a team of monitoring and evaluation in order to improve. Ironically, based on preliminary observations conducted by researchers, it was noted that monitoring and evaluation were not carried out routinely and continuously.

The focus of this study is on the evaluation of the operational effectiveness of School Operational Assistance (BOS) Program on Islamic Elementary School in Jambi, Indonesia. BOS program evaluation research focus is limited to the period of the fiscal year 2014 and the private Islamic Elementary School. 
Based on the background and the results of the identification of the problem, the formulation of the problem is:

1. How to evaluate the needs assessment in the achievement of goals, objectives and School Operational Assistance (BOS) policy's on private Islamic elementary school?

2. How is the readiness, accuracy and completeness of the program through a plan of activities, procedures, and mechanisms, organizational structure, monitoring and controlling, human resources support, infrastructure, and budget support program in accordance with the objectives and targets of the program?

3. How effective is the implementation / management program action plans, procedures, and mechanisms, organizational structure, monitoring and controlling, human resources support, facilities, and budget?

4. What are the results and benefits of the implementation of the School Operational Assistance (BOS) on private Islamic elementary school in Jambi?

\section{LITERATURE REVIEW}

Key components of a program are human as the target program. This is as stated by Wholey, et.al (2010) stating "A program is a set of resources and activities directed toward one or more common goals, typically under the direction of or single manager or management team. Further declared, a program may consist of a limited set of activities within a single agency or complex activities performed in many places in government institutions or providers of public, nonprofit, and private.

Royse, et.al (2010) state that a program is an organized collection of activities designed to reach certain objectives. A program is a series of organized activities designed to achieve the goals set. There are two main elements in the sense of this program, namely: 1) planning, it shows that the program is implemented based on plans made to resolve the issue; 2) intervention, this shows that the program is an intervention activity or service required in executing a plan.

Chen (2005) defines a program evaluation as the application of evaluation approaches, techniques, and knowledge to systematically assess and improve the planning, implementation, and effectiveness of programs. Any evaluation of the program can be conceived to have five (5) components namely: input, transformation, output, feedback and environment.

Isaac and Michael (1983) a long time ago have stated that the program is a complex process, involving a wide range of components and consider the wholeness.

Based on some understanding of the above, it can be synthesized that program is all activities that are designed to implement a single unit or several components of the planned activities systematically, have clear objectives, implemented strategically whose activities utilizing resources sustainably on an organization by a team to achieve predetermined objectives (outputs and outcomes). The indicator of the program is characterized by 1) designing of the program; 2) the purpose and objectives of the program; 3) resource executor; 4) the implementing organization, and 5) benefits (product).

Evaluation of the program according to Langbein and Felbinger (2006) is the application of empirical social science research methods to the process of judging the effectiveness of public policies, programs, or projects, as well as their management and implementation, for decision -making purposes.

Evaluation of programs aimed at the business improvement program as stated by Melvin, et.al (2000) aims to:

- Assessment of merit and worth: the development of warranted judgments, at the individual and societal level, of the value of a policy or program.

- Program and organizational improvement: the effort to use information to directly modify and enhance program operations.

- Oversight and compliance: the assessment of the extent to which a program follows the directives of statutes, regulations, rules, mandated standards or any other formal expectations.

- Knowledge development: the discovery or testing of general theories, propositions, and hypothesis in the context of policies and programs. 
There are many models to evaluate the program, such as; Provus models (Discrepancy Model), a model Stake (Countenance Model), Formative-Summative Evaluation Model, a CSE-UCLA model and the CIPP Model. From some consideration of the use of the methods of evaluation programs mentioned above, this study used CIPP model evaluation because of the four components of context, input, process, and product (result) are a unified a whole reflecting the strengths of CIPP models (Zhang, et.al, 2011). Specifically, the context evaluation component of the Context, Input, Process, and Product evaluation model can help identifying service providers' learning needs and the community's needs. The input evaluation component can then help prescribe a responsive project that can best address the identified needs. Next, the process evaluation component monitors the project process and potential procedural barriers and identifies needs for project adjustments. Finally, the product evaluation component measures interpret, and judges project outcomes and interpret their merit, worth, significance, and probity.

Description CIPP program evaluation model and the indicators contained in any aspect / stage of the research above, the application of the model CIPP evaluation model program in this study, can be described in the following table:

Table1. Implementation CIPP Evaluation Model in School Operational Assistance or Bantuan Operational Sekolah (BOS) Program

\begin{tabular}{|c|c|c|c|}
\hline CONTEXT & INPUT & PROCESS & PRODUCT \\
\hline $\begin{array}{c}\text { Assessing the } B O S \\
\text { program objectives } \\
\text { are oriented to the } \\
\text { needs of schools and } \\
\text { students, the terms } \\
\text { formulation of } \\
\text { objectives, goals, and } \\
\text { policies that underlie } \\
\text { the BOS program }\end{array}$ & $\begin{array}{c}\text { Assessing the readiness of } \\
\text { implementing the program } \\
\text { includes action plans, } \\
\text { procedures, and mechanisms, } \\
\text { organizational structure, } \\
\text { monitoring and controlling, } \\
\text { human resources support, } \\
\text { infrastructure, and budget }\end{array}$ & $\begin{array}{c}\text { Assess the effectiveness and } \\
\text { efficiency of BOS program } \\
\text { implementation to see the accuracy } \\
\text { of program action plans, procedures, } \\
\text { and mechanisms, organizational } \\
\text { structure, monitoring, and control. } \\
\text { In addition, the support of } \\
\text { implementation in human resources, } \\
\text { infrastructure, and budgets }\end{array}$ & $\begin{array}{c}\text { Assessing } \\
\text { the results of } \\
\text { ine form } \\
\text { ond benefits } \\
\text { BOS }\end{array}$ \\
program \\
\hline
\end{tabular}

To sum up the model in the School Operational Assistance (BOS) in this research is categorized as 1) the basic needs of the activities (context), 2) preparatory activities (input), 3) implementing activities (processes), 4) the result (product).

\section{Methodology}

This study is the evaluation research on a program by using a descriptive qualitative approach with CIPP (Context, Input, Process, and Product) models developed by Stufflebeam (2003). In order to obtain primary data in this study, data collection is obtained through observation, interviews, documentation, Forum Group Discussion (FGD) and triangulation. These instruments are used to obtain substantive and important information affecting the enforceability of the implementation of School Operational Assistance program at 3 private elected Islamic elementary school in the city of Jambi. The 4 (four) key informants were asked to assess the successfulness of program implementation by giving rank 1 to 5 indicating $1=$ very poor, $2=$ poor, $3=$ pretty good, $4=$ good, 5 $=$ very good. Documents are verified by interviewers by using the same rating to indicate the readiness.

\section{RESUlT AND DISCUSSION}

\subsection{Context}

The context of evaluation component contains goal setting, objective setting, and the policy of BOS. The assessment results obtained from the context evaluation category are documented as follows:

Table2. Recapitulation of Interview Results and Documentation of Context Aspects

\begin{tabular}{|c|c|c|c|c|c|c|}
\hline \multirow{2}{*}{ No. } & \multirow{2}{*}{ Component } & \multicolumn{4}{|c|}{ Evaluation } & \multirow{2}{*}{ Average } \\
\hline & & Informant 1 & Informant 2 & Informant 3 & Documents & \\
\hline 1 & Goal Setting & 4.6 & 4.6 & 5 & 4 & 4.6 \\
\hline 2 & Objective Setting & 5 & 4.3 & 5 & 5 & 4.8 \\
\hline 3 & Policy & 5 & 5 & 5 & 4 & 4.8 \\
\hline
\end{tabular}

Based on the recapitulation of context aspects, it is observable that: 
- In the goal-setting component, informants and documentation study results provide an assessment of an average value of 4.6 out of 5 meaning that goal setting has been accomplished excellently.

- Similarly in the objective setting component, informants and documentation study results provide an assessment of an average value of 4.8 out of 5 meaning that goal setting has been accomplished excellently as well.

- Finally, the same things also happen in policy components where average value generated is 4.8 out of 5 meaning that goal setting has been accomplished excellently also.

From the answers of informants and documentation of study results, it is concluded that the management team has conducted assessments of the needs in the context of goal setting, objective setting and policies excellently proved with the average score approaching the highest score of 5 (five). Thus, all aspects of the input component of the BOS program can still be maintained while planning all activities more focus on targeted activities based on the characteristics of each schools, coordinating and involving all stakeholders in accordance with their competence in supporting the success of the BOS program as well as the dissemination and deployment of information to all citizens.

\subsection{Input}

Input evaluation is to analyze the preparatory activities to achieve the goal of BOS. In this study, it includes the components of action plans, procedures, and mechanisms, organizational structure, monitoring and controlling, human resources support, infrastructure support, and the budget of the program. The assessment results obtained from the input evaluation category are documented as follows:

Table3. Recapitulation of Interview Results and Documentation of Input Aspects

\begin{tabular}{|c|c|c|c|c|c|c|}
\hline \multirow{2}{*}{ No. } & \multirow{2}{*}{ Component } & \multicolumn{4}{|c|}{ Evaluation } & \multirow[t]{2}{*}{ Average } \\
\hline & & Informant 1 & Informant 2 & Informant 3 & Documents & \\
\hline 1 & action plans & 4.7 & 4.3 & 5 & 5 & 4.8 \\
\hline 2 & procedures and mechanisms & 4 & 4 & 5 & 4 & 4.3 \\
\hline 3 & organizational structure & 4 & 4.3 & 4 & 5 & 4.3 \\
\hline 4 & monitoring and controlling & 4 & 4 & 5 & 3 & 4.0 \\
\hline 5 & human resources & 3.5 & 3.5 & 5 & 3 & 3.8 \\
\hline 6 & infrastructure & 4 & 4 & 5 & 3 & 4.0 \\
\hline 7 & budget & 4 & 4 & 4.8 & 4 & 4.2 \\
\hline
\end{tabular}

The above score indicates that the management team has made preparation in aspects of input reflected in good scores of the action plan, procedures, and mechanisms, organizational structure, monitoring and controlling, infrastructure as well as budget. Only in human resources aspects the average score below 4 (good) that requires attention to obtain full support for achieving the objective. Thus, all aspects of the input components of the BOS program can still be maintained through constant anticipation of planning when there is a change of activity, clarity schedule for each activity, the coordination and the involvement of all stakeholders of school in accordance with their competence in supporting the success of the BOS program as well as to socialize and disseminate the relevant information openly and publicly.

\subsection{Process}

Process evaluation is to analyze the implementation activities to achieve the goal of BOS. Similar to input process study, it includes the components of action plans, procedures, and mechanisms, organizational structure, monitoring and controlling, human resources support, infrastructure support, and the budget of the program. The assessment results obtained from the process evaluation category are documented as follows:

The score reveals that the management team has successfully implemented steps necessary in process aspects reflected in good scores of an action plan, organizational structure, monitoring and controlling, human resources, infrastructure as well as budget. Only in aspects the procedures and mechanisms average score below 4 meaning that effort must be made to make this component achieves the expected level. This way, all aspects of the process components of the BOS program can still be preserved through continuous anticipation of planning when there is a change of activity, 
clarity schedule for each activity, the coordination and the contribution of all stakeholders of school in accordance with their competence in supporting the success of the BOS program as well as to socialize and spread the relevant information.

Table4. Recapitulation of Interview Results and Documentation of Process Aspects

\begin{tabular}{|c|c|c|c|c|c|c|}
\hline \multirow{2}{*}{ No. } & \multirow{2}{*}{ Component } & \multicolumn{4}{|c|}{ Evaluation } & \multirow[t]{2}{*}{ Average } \\
\hline & & Informant 1 & Informant 2 & Informant 3 & Documents & \\
\hline 1 & action plans & 4 & 4.7 & 5 & 4 & 4.4 \\
\hline 2 & procedures and mechanisms & 4 & 4 & 5 & 1 & 3.5 \\
\hline 3 & organizational structure & 4.5 & 4 & 5 & 3 & 4,1 \\
\hline 4 & monitoring and controlling & 4 & 4 & 5 & 3 & 4,0 \\
\hline 5 & human resources & 4 & 4 & 5 & 3 & 4,0 \\
\hline 6 & infrastructure & 4 & 5 & 5 & 3 & 4.3 \\
\hline 7 & budget & 4 & 4.5 & 4 & 4 & 4.1 \\
\hline
\end{tabular}

\subsection{Product}

Evaluation of the production is an activity to analyze the results on the achievement of program objectives of BOS. In this study, the evaluation process includes the components of result and benefits achievement of the program implementation. The assessment results obtained from the product evaluation category are documented as follows:

Table5. Recapitulation of Interview Results and Documentation of Product Aspects

\begin{tabular}{|c|c|c|c|c|c|c|}
\hline \multirow{2}{*}{ No. } & \multirow{2}{*}{ Component } & \multicolumn{4}{|c|}{ Evaluation } & \multirow{2}{*}{ Average } \\
\cline { 3 - 6 } & & Informant 1 & Informant 2 & Informant 3 & Documents & \\
\hline 1 & Result Achievement & 4.5 & 4 & 4.5 & 5 & 4.5 \\
\hline 2 & Benefit Achievement & 4.5 & 5 & 5 & 5 & 4.9 \\
\hline
\end{tabular}

The score reveals that the management team has successfully achieved the excellent level in product aspects reflected in good scores of achievement and benefits results component as the average score is 4.7 (very good). Consequently, alike other aspects, the product components of the BOS program can still be preserved.

\section{Conclusion}

Referring to the results of the analysis of data on the activities of School Operational Assistance (BOS) in 2014 on private Islamic elementary school in the city of Jambi, Indonesia, the general implementation of programs has been better in improving the service, access, and quality of education. Therefore, the BOS can be maintained and continued. The research pinpoints some important considerations

First, the results of the evaluation aspects of the context of the BOS program falls in a very good category. However, analysis of needs assessment in the formulation of goal attainment is not entirely based on the results of the evaluation of program activities conducted in the previous year as an effort to improve the quality, service, access and education in madrasas.

Second, the results of the evaluation aspects of input activities of the program fall under good categories. Preparation of the organizational structure of the program activities has involved headmaster, teachers, administration staff and school committee although the appointment of personnel is conducted directly by the headmaster.

Third, the results of the evaluation process aspect also fall in good categories. BOS program planning implementation activities are in accordance with the plan set by the technical instructions. Analysis of the implementation of the plan still needs to be done anyway.

Finally and most important, the results of the evaluation aspects of the product activity of BOS program fall into the very good category. Result achievement and benefits achievement of the BOS program in Jambi was as successful in improving the quality, achievement, access, and educational services at the school. 


\section{REFERENCES}

Chen, Huey Tsyh (2005). Practical Program Evaluation: Assessing and improving Planning, Implementation, and Effectiveness, Thousand Oaks: Sage Publications, pp. 3.

Isaac, Stephen and William B. Michael (1983). Handbook is Research and Evaluation, San Diego: EdiTs Publishers, pp. 8 - 9.

Langbein, Laura \& Claire L. Felbinger (2006). Public Program Evaluation: A Statistical Guide, New York: M.E. Sharpe, Inc., pp. 3.

Melvin M. Mark, Gary T. Henry, \& Julnes, G. (2000). Evaluation: An integrated framework for understanding, guiding and improving policies and programs. Jossey-Bass Pfeiffer.

Royse, David, Bruce A. Thyer, and Deborah K. Padgett (2010). Program Evaluation: An Introduction, Fifth Edition, USA: Wadsworth, pp. 5.

Stufflebeam, D. L. (2003). The CIPP model for evaluation. In International handbook of educational evaluation (pp. 31-62). Springer Netherlands.

Wholey, Joseph S., Harry P. Hatry and Kathryn E. Newcomer (2010). Handbook of Practical Program Evaluation, Third Edition, San Francisco, CA: John Wiley \& Sons, Inc., pp. 5.

Zhang, G., Zeller, N., Griffith, R., Metcalf, D., Williams, J., Shea, C., \& Misulis, K. (2011). Using the context, input, process, and product evaluation model (CIPP) as a comprehensive framework to guide the planning, implementation, and assessment of service-learning programs. Journal of Higher Education Outreach and Engagement, 15(4), 57-84. 